\title{
Sifat Beton Ringan Struktural dengan Agregat Ringan Buatan dari Tanah Diatomae di bawah Beban Tekan
}

\author{
Nurul Husna ${ }^{1}$ Muttaqin $^{2}$ Taufiq Saidi ${ }^{3}$ \\ 1,2,3 Jurusan Teknik Sipil, Universitas Syiah Kuala, Banda Aceh 23111, Indonesia \\ Email: nurulhusnaar81@gmail.com
}

\begin{abstract}
The development of lightweight concrete usage is increasing. One method to obtain lightweight concrete is by using lightweight aggregates as a lightweight concrete mixture. Diatomaceous earth is an alternative that can be used as a lightweight aggregates in concrete mixture. The artificial lightweight coarse aggregates made from diatomaceous earth as varried into 2 types, the artficial lightweight coarse aggregates from diatomaceous earth and the artificial lightweight coarse aggregate from diatomaceous earth mixture and 5\% sawdust. The objective of this study is to determine the value of concrete compressive strength the relationship of stress-strain, the modulus of elasticity, and crack patterns in structural lightweight concrete by using artificial lightweight coarse aggregates from diatomaceous earth. According to the results of the study, the highest average compressive strength was obtain in lightweight concrete with an artificial coarse aggregates from diatomaceous earth which amounted to 17,599 MPa therefore it met the requirements as structural lightweight concrete. The highest average modulus of elasticity was also in the lightweight concrete with artificial coarse aggregate from diatomaceous earth of 12110,11 MPa. The pattern of concrete destruction that occurs is the pattern of shear, cone and shear, and cone and split.
\end{abstract}

Keywords: Structural Lightweight Concrete, Lightweight Aggregates, Diatomaceous Earth, Compressive Strength, Modulus of Elasticity.

\begin{abstract}
Abstrak
Perkembangan penggunaan beton ringan semakin meningkat. Salah satu cara mendapatkan beton ringan yaitu menggunakan agregat ringan sebagai campuran beton ringan. Tanah diatomae merupakan alternatif yang dapat digunakan sebagai agregat ringan dalam campuran beton. Agregat kasar ringan buatan yang dibuat dari tanah diatomae divariasikan menjadi 2 macam, yaitu agregat kasar ringan buatan dari tanah diatomae serta agregat kasar ringan buatan dari campuran tanah diatomae dan 5\% serbuk gergaji. Penelitian ini bertujuan untuk mengetahui kuat tekan, hubungan tegangan regangan, modulus elastisitas dan pola retak beton ringan struktural dengan agregat ringan buatan dari tanah diatomae. Hasil penelitian menunjukkan nilai kuat tekan rata-rata terbesar terdapat pada beton ringan dengan agregat kasar buatan dari tanah diatomae yaitu sebesar 17,599 MPa sehingga memenuhi persyaratan sebagai beton ringan struktural. Nilai modulus elastisitas rata-rata terbesar juga pada beton ringan dengan agregat kasar buatan dari tanah diatomae yaitu sebesar 12110,11 MPa. Pola kehacuran beton yang terjadi yaitu pola kehancuran geser, kerucut dan geser, serta kerucut dan belah.
\end{abstract}

Kata Kunci: Beton Ringan Struktural, Agregat Ringan, Tanah Diatomae, Beban Tekan, Modulus Elastisitas.

\section{Pendahuluan}

Pada era globalisasi kini pembangunan proyek konstruksi yang terjadi di Indonesia semakin intens. Hal ini pasti akan menambah kebutuhan material yang digunakan dalam pembangunan struktur, sepeti agregat. Agregat yaitu material yang digunakan dalam campuran beton.

Dalam dunia konstruksi sekarang sudah banyak menggunakan beton ringan, karena penggunaan beton ringan dalam suatu konstruksi dapat mengurangi beban mati suatu struktur bangunan. Beton ringan yang digunakan dalam konstruksi yaitu beton ringan struktural. Salah satu metode yang digunakan untuk mendapatkan beton ringan yaitu dengan menggunakan agregat ringan dalam campuran beton. Salah satu jenis agregat ringan yang dapat digunakan dalam pembuatan

Journal of The Civil Engineering Student

Vol. 3. No. 1, April 2021, Halaman 85-91 beton ringan struktural yaitu agregat ringan yang berasal dari tanah diatomae.

Pada penelitian ini akan dikembangkan beton ringan struktural dengan cara membuat agregat ringan yang berasal dari tanah diatomae yang lebih kuat. Metode untuk memperoleh kuat tekan beton yang lebih tinggi dapat dipelajari dari penelitian sebelumnya yang relevan. Dalam penelitian ini akan digunakan metode pembuatan agregat ringan yang diajukan oleh Fragoulis et.al[1].

Penelitian ini memiliki tujuan untuk mengetahui nilai kuat tekan, hubungan tegangan-regangan, modulus elastisitas, dan pola kehancuran beton ringan struktural dengan menggunakan agregat ringan yang berbahan dasar dari tanah diatomae.

Batasan penelitian, diantaranya yaitu agregat kasar ringan buatan yang dibuat dari tanah diatomae divariasikan menjadi 2 macam, yaitu agregat kasar 
ringan buatan yang dibuat dari tanah diatomae tanpa tambahan serbuk gergaji, serta agregat kasar ringan buatan yang dibuat dari campuran tanah diatomae dan $5 \%$ serbuk gergaji. Benda uji yang digunakan berbentuk silinder yang berukuran $10 \mathrm{~cm}$ x $20 \mathrm{~cm}$. Jumlah benda uji untuk masing-masing variasi agregat kasar ringan buatan adalah sebanyak 5 benda uji sehingga total benda uji adalah 10 buah. Pengujian dilakukan saat benda uji berumur 28 hari.

Berdasarkan hasil penelitian dan pengolahan data penggunaan agregat kasar ringan buatan dari tanah diatomae berpengaruh terhadap besarnya nilai kuat tekan beton ringan yang diperoleh. Dari nilai kuat tekan dan berat isi beton ringan menggunakan kedua variasi agregat kasar ringan buatan dari tanah diatomae yang diperoleh dapat dimasukkan kedalam spesifikasi menurut SNI 03-3449-2002. Dari hasil pengujian kuat tekan beton diperoleh kuat tekan rata-rata terbesar untuk beton ringan dengan agregat kasar ringan buatan dari tanah diatomae yaitu sebesar 17,599 $\mathrm{MPa}$ dengan berat isi rata-rata $1872,90 \mathrm{~kg} / \mathrm{m}^{3}$, sehingga beton ringan dengan variasi ini termasuk beton ringan struktural. Sedangkan nilai kuat tekan beton rata-rata dengan agregat kasar ringan buatan dari campuran tanah diatomae dan 5\% serbuk gergaji yaitu sebesar 15,368 $\mathrm{MPa}$, sehingga beton ringan yang dihasilkan untuk variasi ini termasuk beton ringan struktural ringan. Nilai modulus elastisitas rata rata terbesar juga terdapat pada beton ringan dengan agregat ringan buatan dari tanah diatomae yaitu sebesar 12110,11 MPa. Pola kehancuran beton yang terjadi cukup bervariasi yaitu, pola kehancuran geser, kerucut dan geser, serta kerucut dan belah.

\section{Tinjauan Kepustakaan}

\subsection{Agregat Ringan}

Agregat adalah salah satu material inti yang digunakan dalam campuran beton yang saling diikat oleh bahan perekat semen. Berdasarkan SNI 2847:2013[2], agregat ringan (lightweight aggregate) adalah agregat yang memiliki berat volume (density) gumpalan (bulk) lepas sebesar $1120 \mathrm{~kg} / \mathrm{m}^{3}$ atau kurang. Menurut Mulyono[3], kepadatan agregat ringan adalah pada jarak sekitar 300 sampai dengan $1850 \mathrm{~kg} / \mathrm{m}^{3}$. Pada umumnya, agregat ringan adalah agregat yang memiliki berat jenis yang ringan, memiliki porositas yang tinggi, serta memiliki kemampuan penghantar panas yang rendah. Agregat dapat berupa agregat ringan alami dan agregat ringan buatan.

\subsection{Beton Ringan}

Beton ringan merupakan beton yang pembuatannya berasal dari agregat ringan. Berdasarkan ACI 213R-03[4], beton ringan adalah beton yang mempunyai nilai bulk antara $1190 \mathrm{~kg} / \mathrm{m}^{3}$ sampai 1920 $\mathrm{kg} / \mathrm{m}^{3}$. Beton ringan struktural yaitu beton yang dapat dimanfaatkan untuk kebutuhan struktural. Menurut SNI 03-3449-2002[5], beton ringan struktural adalah beton yang memiliki agregat ringan atau campuran agregat kasar ringan dan pasir alam sebagai pengganti agregat halus ringan dengan ketentuan tidak boleh melampaui berat isi maksimum beton $1850 \mathrm{~kg} / \mathrm{m}^{3}$ dan harus memenuhi ketentuan kuat tekanan dan kuat tarik belah beton ringan untuk tujuan struktural.

Menurut SNI 03-3449-2002[5], jenis beton ringan diklasifikasikan berdasarkan nilai kuat tekan, nilai berat beton, dan agregat penyusunnya yang dapat dilihat pada Tabel 1 .

Tabel 1 Jenis-Jenis Beton Ringan Berdasarkan Kuat Tekan, Berat Beton, dan Agregat Penyusunnya

\begin{tabular}{|c|c|c|c|}
\hline \multirow[b]{2}{*}{$\begin{array}{c}\text { Konstruksi } \\
\text { Beton Ringan }\end{array}$} & \multicolumn{2}{|c|}{ Beton Ringan } & \multirow[b]{2}{*}{ Jenis Agregat Ringan } \\
\hline & $\begin{array}{l}\text { Kuat } \\
\text { Tekan } \\
\text { (MPa) }\end{array}$ & $\begin{array}{c}\text { Berat Isi } \\
\left(\mathrm{Kg} / \mathbf{m}^{3}\right)\end{array}$ & \\
\hline $\begin{array}{l}\text { Struktural } \\
\text { Minimum } \\
\text { Maksimum }\end{array}$ & $\begin{array}{l}17,24 \\
41,36\end{array}$ & $\begin{array}{l}1400 \\
1850\end{array}$ & $\begin{array}{l}\text { Agregat yang dibuat } \\
\text { melalui proses } \\
\text { pemanasan batu serpih, } \\
\text { batu apung, batu sabak, } \\
\text { terak besi atau abu } \\
\text { terbang; }\end{array}$ \\
\hline $\begin{array}{l}\text { Struktural } \\
\text { ringan } \\
\text { Minimum } \\
\text { Maksimum }\end{array}$ & $\begin{array}{c}6,89 \\
17,24\end{array}$ & $\begin{array}{c}800 \\
1400\end{array}$ & $\begin{array}{l}\text { Agregat ringan alami } \\
\text { seperti skoria atau batu } \\
\text { apung }\end{array}$ \\
\hline $\begin{array}{l}\text { Struktural } \\
\text { sangat ringan } \\
\text { sebagai isolasi } \\
\text { Minimum } \\
\text { Maksimum }\end{array}$ & $\begin{array}{l}- \\
-\end{array}$ & $\begin{array}{c}- \\
800\end{array}$ & Perlit atau vermikulit \\
\hline
\end{tabular}

\subsection{Tanah Diatomae}

Definisi tanah diatomae adalah tanah yang mempunyai komposisi kimiawi berupa silika amorf dengan kadar mencapai sekitar 55-70\%, tergantung dengan lokasinya[6]. Kadar senyawa silika dalam struktur tanah diatomae sangat beragam. Keberagaman tersebut sangat bergantung pada lokasi tanah diatomae tersebut[7]. Menurut Hidayati (2007) yang dikutip oleh Abida[8], komposisi kimia tanah diatomae terdiri dari $86 \%$ silika, $5 \%$ natrium, $3 \%$ magnesium, dan $2 \%$ besi.

Menurut Kirk dan Othmer[9], silika amorf $\left(\mathrm{SiO}_{2}\right.$ $\mathrm{nH}_{2} \mathrm{O}$ ) terdiri atas atom silikon dan oksigen yang merupakan komposisi tanah diatomae yang tersusun secara tetrahidron hampir sama seperti silika kristal tetapi jaringannya tidak terulang secara periodik dan simetri seperti halnya pada kristal. Didalam tanah diatomae juga terkandung zat organik dan oksida logam yang dapat menghambat daya serap ion logam. Proses kalsinasi akan mengurangi zat organik dan oksida logam selain $\mathrm{SiO}_{2}$ sehingga $\mathrm{SiO}_{2}$ semakin dominan.

Fragoulis, et al[1], telah menganalisis uji mineral dan kimia untuk diatomaeceous earth dari Elassona. Diperoleh hasil bahwa diatomaeceous earth dari Elassona terdiri dari Opal-A, clay mineral, fieldspars, dan quartz. Sehingga diatomit Samos kaya kalsium oksida dan silikon dioksida, untuk diatomaeceous earth dari Elassona kaya silikon dioksida, aluminium oksida, dan besi (III) oksida.

Gambar hasil uji SEM diatomaeceous earth dari Ellasona, Yunani diperlihatkan pada Gambar 1. 
Dimana :

$E=$ Modulus of elasticity beton (MPa);

$\mathrm{S}_{2}=$ Tegangan pada saat beban mencapai $40 \%$ dari beban maksimum;

$\mathrm{S}_{1}=$ Tegangan yang terjadi ketika regangan longitudinal mencapai 0,000050 ;

$\varepsilon_{2}=$ Regangan longitudinal pada saat beban mencapai $40 \%$ dari beban maksimum

\subsection{Hubungan Tegangan dan Regangan}

Menurut Gere dan Timoshenko[12], menyatakan bahwa besarnya regangan yang terjadi dapat dihitung dengan menggunakan Persamaan 3.

$\varepsilon=\frac{\Delta L}{L}$

\section{Gambar 1 Struktur Tanah Diatomae}

\subsection{Serbuk Gergaji}

Serbuk gergaji adalah ampas pengolahan dari penggergajian kayu dapat dijadikan bahan tambah di dalam agregat ringan buatan.

\subsection{Kuat Tekan Beton}

Berdasarkan SNI 03-1974-1990[10], kuat tekan beton adalah beban yang diberikan per satuan luas yang mengakibatkan benda uji silinder hancur bila diberi beban tekan tertentu pada saat pengujian.

Kuat tekan beton dapat dihitung dengan menggunakan Persamaan 1.

$f^{\prime} c=\frac{P}{A}$

Dimana :

$f^{\prime} c=$ Kuat tekan beton benda uji silinder $(\mathrm{MPa})$;

$\mathrm{P}=$ Besar beban maksimum yang bekerja $(\mathrm{N})$; dan

$\mathrm{A}=$ Luas penampang benda uji $\left(\mathrm{mm}^{2}\right)$.

\subsection{Pola Kehancuran Beton}

Pola kehancuran terbentuk karena adanya gaya tekan dari atas dan bawah pada benda uji silinder. Pola kehancuran beton terdiri dari lima jenis yaitu:

1. Bentuk kehancuran kerucut;

2. Bentuk kehancuran kerucut dan belah

3. Bentuk kehancuran kerucut dan geser;

4. Bentuk kehancuran geser; dan

5. Bentuk kehancuran kolumnar.
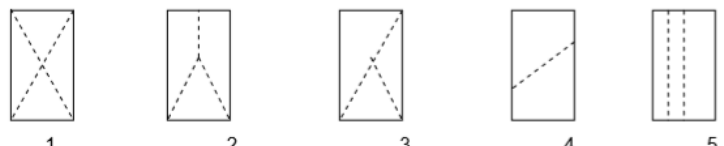

Gambar 2 Pola Kehancuran Beton

\subsection{Modulus Elastisitas}

Modulus elastisitas adalah rasio tegangan normal terhadap regangan terkait untuk tegangan tarik atau tekan di bawah batas proporsional[11]. Menurut ASTM C469-02[12], persamaan untuk menghitung nilai modulus of elasticit diperlihatkan pada Persamaan 2:

$E=\frac{S_{2}-S_{1}}{\varepsilon_{2}-0,00005}$

Journal of The Civil Engineering Student

Vol. 3. No. 1, April 2021, Halaman 85-91
Dimana :

$\varepsilon \quad=$ Regangan;

$\Delta L=$ Besar Perpendekan yang terjadi (mm); dan

$\mathrm{L}=$ Panjang pengamatan awal $(\mathrm{mm})$.

\section{Metodologi Penelitian}

Langkah dalam penelitian ini dimulai dengan persiapan material dan peralatan, pembuatan agregat ringan, pemeriksaan sifat fisis agregat, rancangan mix design beton ringan, pembuatan benda uji, perawatan benda uji, pengujian benda uji, dan pengolahan data.

\subsection{Sumber Data}

Data-data yang dikumpulkan untuk mendukung penelitian ini didapatkan dari pengujian yang dilakukan di laboratorium, hasil-hasil penelitian sebelumnya yang berhubungan dengan penelitian yang dilakukan, dan referensi-referensi sebagai sumber data. Data yang dikumpulkan selama penelitian meliputi data pengujian sifat-sifat fisis agregat (bulk density, specific gravity, absorption, dan fineness modulus), hasil perencanaan proporsi campuran beton, hasil pengujian kuat tekan, modulus elastisitas, dan hubungan tegangan-regangan.

\subsection{Material dan Peralatan}

Material yang digunakan dalam penelitian tugas akhir ini adalah Semen Portland, agregat halus, tanah diatomae, serbuk gergaji, dan air. Pada penelitian ini menggunakan semen portland tipe I yang merupakan produksi dari PT. Semen Andalas Indonesia (SAI). Peralatan yang dipakai adalah oven, mesin pengaduk beton (concrete mixer), cetakan benda uji silinder $10 \mathrm{~cm}$ x $20 \mathrm{~cm}$, mesin uji kuat tekan beton, LVDT, mesin los angeles, dan peralatan penunjang lainnya.

\subsection{Pembuatan Agregat Kasar Ringan}

Agregat kasar ringan yang digunakan dalam campuran beton dibuat menjadi dua variasi. Sebelum digunakan dalam campuran, bongkahan tanah diatomae terlebih dahulu dihancurkan dengan menggunakan palu, kemudian tanah dioven pada suhu $100{ }^{\circ} \mathrm{C}$ selama 24 jam, lalu tanah diatomae yang telah dioven dihancurkan dengan menggunakan mesin Los Angeles hingga menjadi debu, setelah dihancurkan dengan mesin Los 
Angeles tanah diatomae diayak dengan menggunakan ayakan no. 200. Kemudian tanah diatomae yang telah diayak dicampur dengan air (variasi 1); serta dicampur dengan 5\% serbuk gergaji dengan ukuran partikel kurang dari $1 \mathrm{~mm}$ dan air (variasi 2). Setelah menjadi campuran, tanah diatomae dibuat menjadi bulat-bulatan kecil (dipelet) dengan ukuran 5-20 $\mathrm{mm}$ untuk dijadikan sebagai agregat kasar. Setelah dipelet, agregat dikeringkan dalam oven selama 24 jam. Kemudian agregat dibakar pada tungku pembakaran batu bata di Desa Lamreung, Kabupaten Aceh Besar. Selain dibuat menjadi bulat-bulatan berukuran 5-19 mm, juga dibuat benda uji berbentuk kubus dengan sisi $5 \mathrm{~cm}$ untuk diuji kuat tekan agregat.

\subsection{Pembuatan dan Perawatan Benda Uji Silinder}

Pencampuran beton ringan dibuat dengan cara memasukkan campuran pembetuk beton ringan secara berturut-turut ke dalam molen yaitu agregat kasar ringan buatan, agrgat halus, semen, dan air. Setelah pengadukan homogen maka dilakukan pengujian slump. Setelah itu campuran beton dimasukkan ke dalam cetakan silinder. Setelah benda uji berumur 2-4 jam, permukaannya diratakan dengan menggunakan pasta semen (capping). Perawatan (curing) beton dilakukan setelah campuran beton mengeras, kemudian beton dikeluarkan dari cetakan dan diberikan kode pada setiap benda uji sesuai dengan yang direncanakan. Perawatan (curing) dilakukan dengan merendam beton ke dalam air selama umur beton yang telah ditetapkan.

\subsection{Pengujian Kuat Tekan, Hubungan Teganga- Regangan, dan Modulus Elastisitas}

Pengujian kuat tekan beton dilakukan pada umur 28 hari. Pengujian dilakukan dengan mesin uji kuat tekan (compressive loading machine). Benda uji yang diuji yaitu benda uji berbentuk silinder dengan ukuran diameter $10 \mathrm{~cm}$ x tinggi $20 \mathrm{~cm}$. Sebelum dilakukan pengujian, benda uji ditimbang beratnya dan diukur dimensinya. Pembebanan kuat tekan dilakukan hingga benda uji hancur. Pada saat pengujian tekan ini, juga diukur perpendekan benda uji untuk tiap-tiap pertambahan beban hingga benda uji silinder hancur. Perpendekan benda uji diukur dengan menggunakan LVDT. Berdasarkan data yang diperoleh dihitung tegangan regangan kemudian setelah diperoleh nilai tegangan dan regangan dapat dihitung nilai modulus elastisitas.

\section{Hasil dan Pembahasan}

\subsection{Hasil}

\subsubsection{Pemeriksaan Sifat Fisis Agregat}

Hasil pemeriksaan sifat fisis menunjukkan bahwa agregat yang digunakan memenuhi syarat sebagai pembentuk beton. Adapun nilai sifat fisis dapat dilihat pada Tabel 2, Tabel 3, dan Tabel 4.

\section{Tabel 2 Pemeriksaan Sifat Fisis Agregat Kasar dari Tanah Diatomae}

\begin{tabular}{ccccc}
\hline No & $\begin{array}{c}\text { Jenis } \\
\text { Pemeriksaan }\end{array}$ & $\begin{array}{c}\text { Hasil } \\
\text { Penelitian }\end{array}$ & \multicolumn{2}{l}{ Nilai Batas } \\
\hline 1 & Berat Volume & $0,724 \mathrm{~kg} / 1$ & $\begin{array}{c}0,650- \\
0,900\end{array}$ & Naville, 2011 \\
\hline 2 & Berat Jenis (SSD) & 1,645 & $<2,0$ & Teknologi Bahan \\
\hline 3 & Berat Jenis (OD) & 1,461 & $1,2-1,5$ & Naville, 2011 \\
\hline 4 & Absorpsi & $13,253 \%$ & $<15 \%$ & Naville, 2011 \\
\hline 5 & Fineness Modulus & 6,665 & $5,5-8,0$ & Naville, 2011 \\
\hline
\end{tabular}

Tabel 3 Pemeriksaan Sifat Fisis Agregat Kasar dari Tanah Diatomae

\begin{tabular}{ccccc}
\hline No & $\begin{array}{c}\text { Jenis } \\
\text { Pemeriksaan }\end{array}$ & $\begin{array}{c}\text { Hasil } \\
\text { Penelitian }\end{array}$ & \multicolumn{2}{c}{ Nilai Batas } \\
\hline 1 & Berat Volume & $0,623 \mathrm{~kg} / 1$ & $\begin{array}{c}0,650- \\
0,900\end{array}$ & Naville, 2011 \\
\hline 2 & Berat Jenis (SSD) & 1,516 & $<2,0$ & Teknologi Bahan \\
\hline 3 & Berat Jenis (OD) & 1,360 & $1,2-1,5$ & Naville, 2011 \\
\hline 4 & Absorpsi & $11,499 \%$ & $<15 \%$ & Naville, 2011 \\
\hline 5 & Fineness Modulus & 6,874 & $5,5-8,0$ & Naville, 2011 \\
\hline
\end{tabular}

Tabel 4 Pemeriksaan Sifat Fisis Agregat Kasar dari Tanah Diatomae

\begin{tabular}{ccccc}
\hline No & $\begin{array}{c}\text { Jenis } \\
\text { Pemeriksaan }\end{array}$ & $\begin{array}{c}\text { Hasil } \\
\text { Penelitian }\end{array}$ & \multicolumn{2}{c}{ Nilai Batas } \\
\hline 1 & Berat Volume & 1,684 & $>1,2$ & Mulyono, 2004 \\
\hline 2 & Berat Jenis (SSD) & 2,575 & $2,0-2,7$ & Naville, 2011 \\
\hline 3 & Berat Jenis (OD) & 2,518 & $2,0-2,7$ & Naville, 2011 \\
\hline 4 & Absorpsi & 2,272 & $0,4-1,9$ & Orchard \\
\hline 5 & Fineness Modulus & 2,879 & $2,3-3,1$ & ASTM C33 \\
\hline
\end{tabular}

\subsubsection{Perencanaan Proporsi Campuran Beton}

Hasil perencanaan campuran beton dapat dilihat pada Tabel 5.

Tabel 5 Proporsi Campuran Beton Ringan Struktural dengan Agregat Kasar Ringan Buatan per $\mathbf{m}^{3}$

\begin{tabular}{ccccc}
\hline $\begin{array}{c}\text { Variasi } \\
\begin{array}{c}\text { Agregat } \\
\text { Kasar Ringan } \\
\text { Buatan }\end{array}\end{array}$ & $\begin{array}{c}\text { Agregat Kasar } \\
(\mathbf{k g})\end{array}$ & $\begin{array}{c}\text { Pasir } \\
(\mathbf{k g})\end{array}$ & $\begin{array}{c}\text { Semen } \\
(\mathbf{k g})\end{array}$ & $\begin{array}{c}\text { Air } \\
(\mathbf{k g})\end{array}$ \\
\hline KTD & 623,163 & 718,961 & 448,271 & 201,722 \\
\hline KTDSG & 536,230 & 778,309 & 448,271 & 201,722 \\
\hline
\end{tabular}

\subsubsection{Hasil Pengujian Beton Segar}

Hasil pengujian slump dapat dilihat pada Tabel 6 dibawah ini.

\section{Tabel 6 Hasil Pengujian Slump}

\begin{tabular}{ccc}
\hline $\begin{array}{c}\text { Variasi Agregat Kasar } \\
\text { Ringan Buatan }\end{array}$ & KTD & KTDSG \\
\hline Semen $(\mathrm{kg})$ & 20,009 & 20,009 \\
\hline Air $(\mathrm{kg})$ & 9,004 & 9,004 \\
\hline Penambahan Air $(\mathrm{kg})$ & 11 & 10,5 \\
\hline Jumlah Air $(\mathrm{kg})$ & 20,004 & 19,504 \\
\hline Nilai Slump $(\mathrm{cm})$ & 3 & 2,5 \\
\hline
\end{tabular}

\subsubsection{Berat Isi}

Tabel 7.
Hasil pengukuran berat isi dapat dilihat pada 
Tabel 7 Pengukuran Berat Isi Benda Uji Silinder

\begin{tabular}{|c|c|c|c|c|}
\hline \multirow[t]{2}{*}{ Variasi } & $\begin{array}{c}\text { Nama } \\
\text { Benda Uji }\end{array}$ & $\begin{array}{c}\text { Berat } \\
\text { Benda Uji } \\
28 \text { Hari }\end{array}$ & $\begin{array}{c}\text { Berat Isi } \\
\text { Benda Uji } \\
\text { Silinder }\end{array}$ & $\begin{array}{c}\text { Berat Isi } \\
\text { Rata-Rata }\end{array}$ \\
\hline & & (kg) & $\left(\mathrm{kg} / \mathrm{m}^{3}\right)$ & $\left(\mathrm{kg} / \mathrm{m}^{3}\right)$ \\
\hline \multirow{5}{*}{ KTD } & $\mathrm{KTD}_{11}$ & 2,98 & 1882,89 & \multirow{5}{*}{1872,90} \\
\hline & $\mathrm{KTD}_{12}$ & 2,97 & 1864,91 & \\
\hline & $\mathrm{KTD}_{13}$ & 3,07 & 1876,22 & \\
\hline & $\mathrm{KTD}_{14}$ & 3,04 & 1888,40 & \\
\hline & $\mathrm{KTD}_{15}$ & 2,96 & 1852,10 & \\
\hline \multirow{5}{*}{ KTDSG } & $\mathrm{KTDSG}_{11}$ & 2,96 & 1854,54 & \multirow{5}{*}{1856,16} \\
\hline & $\mathrm{KTDSG}_{12}$ & 2,96 & 1873,27 & \\
\hline & $\mathrm{KTDSG}_{13}$ & 2,97 & 1865,23 & \\
\hline & $\mathrm{KTDSG}_{14}$ & 2,90 & 1832,53 & \\
\hline & $\mathrm{KTDSG}_{15}$ & 2,88 & 1855,21 & \\
\hline
\end{tabular}

\subsubsection{Hasil Pengujian Kuat Tekan Beton}

Hasil pengujian kuat tekan beton dapat dilihat pada Tabel 8 .

Tabel 8 Hasil Pengujian Kuat Tekan Beton

\begin{tabular}{|c|c|c|c|}
\hline \multirow[t]{2}{*}{ Variasi } & \multirow{2}{*}{$\begin{array}{c}\text { Nama } \\
\text { Benda Uji }\end{array}$} & $\begin{array}{c}\text { Kuat } \\
\text { Tekan }\end{array}$ & $\begin{array}{c}\text { Kuat Tekan } \\
\text { Rata-Rata }\end{array}$ \\
\hline & & $\left(\mathrm{N} / \mathbf{m m}^{2}\right)$ & $\left(\mathrm{N} / \mathbf{m m}^{2}\right)$ \\
\hline \multirow{5}{*}{ KTD } & $\mathrm{KTD}_{11}$ & 18,203 & \multirow{5}{*}{17,599} \\
\hline & $\mathrm{KTD}_{12}$ & 18,693 & \\
\hline & $\mathrm{KTD}_{13}$ & 16,420 & \\
\hline & $\mathrm{KTD}_{14}$ & 16,497 & \\
\hline & $\mathrm{KTD}_{15}$ & 18,184 & \\
\hline \multirow{5}{*}{ KTDSG } & $\mathrm{KTDSG}_{21}$ & 16,145 & \multirow{5}{*}{15,368} \\
\hline & $\mathrm{KTDSG}_{22}$ & 11,613 & \\
\hline & $\mathrm{KTDSG}_{23}$ & 18,808 & \\
\hline & $\mathrm{KTDSG}_{24}$ & 15,144 & \\
\hline & $\mathrm{KTDSG}_{25}$ & 15,129 & \\
\hline
\end{tabular}

\subsubsection{Penggolongan Kelas Beton Ringan dengan} Agregat Ringan dari Tanah Diatomae

Penggolongan beton ringan dengan agregat kasar ringan buatan dari tanah diatomae diperlihatkan pada Tabel 9.
Tabel 9 Penggolongan Beton Ringan berdasarkan SNI 03-3449-2002

\begin{tabular}{cccc}
\hline \multirow{2}{*}{ Variasi } & $\begin{array}{c}\text { Kuat Tekan } \\
\text { Rata-Rata }\end{array}$ & $\begin{array}{c}\text { Berat Isi } \\
\text { Benda Uji } \\
\text { Rata-Rata }\end{array}$ & $\begin{array}{c}\text { Penggolongan Kelas } \\
\text { Beton Ringan }\end{array}$ \\
\cline { 2 - 3 } & $\mathbf{( N / \mathbf { m m } ^ { \mathbf { 2 } } )}$ & $\mathbf{( k g / \mathbf { m } ^ { \mathbf { 3 } } )}$ & \\
\hline KTD & 17,599 & 1872,90 & Beton Ringan Struktural \\
\hline KTDSG & 15,368 & 1856,16 & $\begin{array}{c}\text { Beton Ringan Struktural } \\
\text { Ringan }\end{array}$ \\
\hline
\end{tabular}

\subsubsection{Hubungan Tegangan dan Regangan Beton}

Data hubungan tegangan-regangan beton ringan dengan agregat kasar ringan buatan dari tanah diatomae didapatkan saat melakukan pengujian kuat tekan beton ringan. Berdasarkan data yang didapatkan, dibuat grafik hubungan tegangan-regangan beton ringan dengan menghitung besarnya nilai tegangan-regangan untuk tiap-tiap pertambahan beban $500 \mathrm{~kg}$ hingga benda uji silinder hancur. Berikut ini adalah grafik hubungan tegangan regangan beton untuk KTD dan KTDSG.

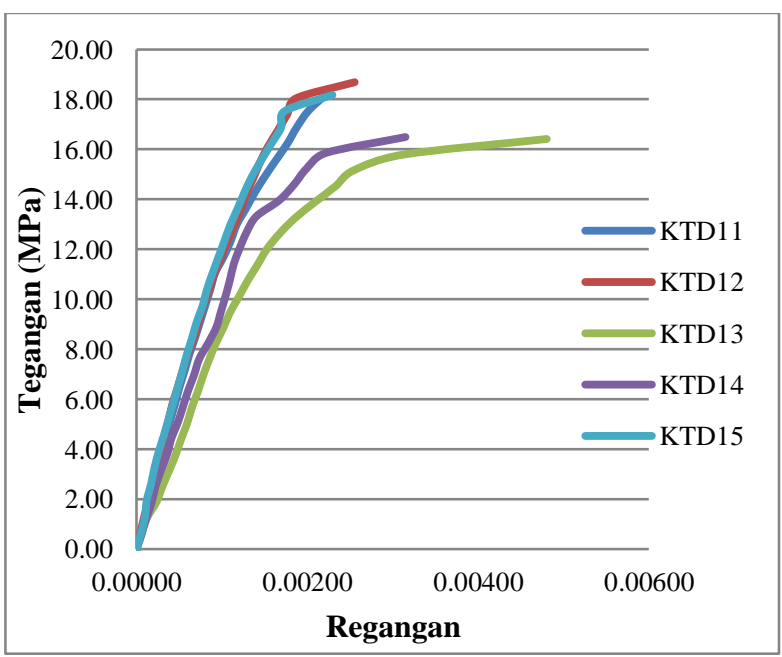

Gambar 4 Grafik Hubungan Tegangan Regangan Beton KTD

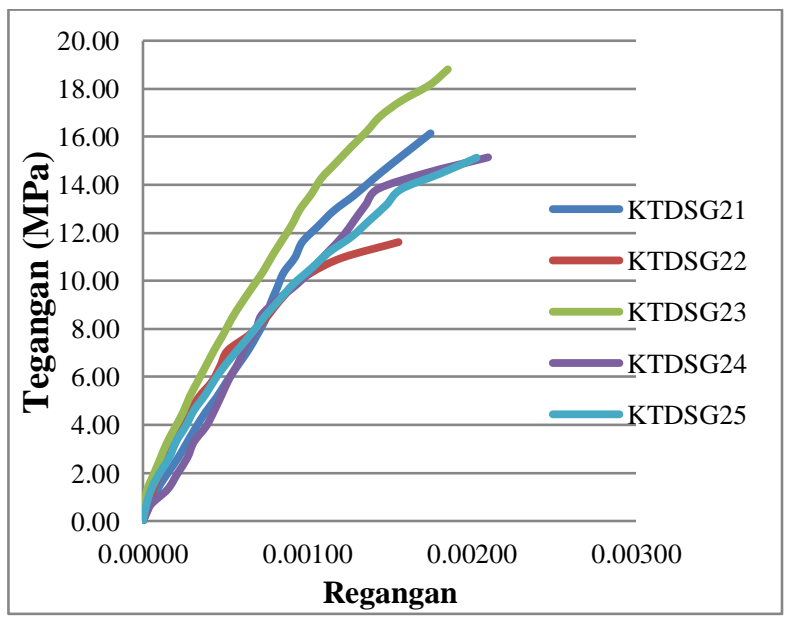

Gambar 5 Grafik Hubungan Tegangan Regangan Beton KTDSG 


\subsubsection{Hasil Pengujian Modulus Elastisitas Beton}

Hasil perhitungan modulus elastisitas beton dilihat pada Tabel 10 .

Tabel 10 Modulus Elastisitas Beton

\begin{tabular}{|c|c|c|c|}
\hline \multirow[t]{2}{*}{ Variasi } & \multirow[t]{2}{*}{$\begin{array}{c}\text { Nama } \\
\text { Benda Uji }\end{array}$} & $\begin{array}{c}\text { Modulus } \\
\text { Elastisitas }\end{array}$ & $\begin{array}{c}\text { Modulus } \\
\text { Elastisitas } \\
\text { Rata-Rata }\end{array}$ \\
\hline & & (MPa) & (MPa) \\
\hline \multirow{5}{*}{ KTD } & $\mathrm{KTD}_{11}$ & 13002,23 & \multirow{5}{*}{12110,11} \\
\hline & $\mathrm{KTD}_{12}$ & 13155,03 & \\
\hline & $\mathrm{KTD}_{13}$ & 10525,46 & \\
\hline & $\mathrm{KTD}_{14}$ & 10477,74 & \\
\hline & $\mathrm{KTD}_{15}$ & 13390,07 & \\
\hline \multirow{5}{*}{ KTDSG } & $\mathrm{KTDSG}_{21}$ & 10863,88 & \multirow{5}{*}{11844,46} \\
\hline & $\mathrm{KTDSG}_{22}$ & 13503,22 & \\
\hline & $\mathrm{KTDSG}_{23}$ & 13734,07 & \\
\hline & $\mathrm{KTDSG}_{24}$ & 10973,82 & \\
\hline & $\mathrm{KTDSG}_{25}$ & 11806,07 & \\
\hline
\end{tabular}

\subsubsection{Pola Kehancuran Beton}

Pola kehancuran terbentuk karena adanya gaya tekan dari atas dan bawah pada benda uji silinder. Retak yang timbul pada benda uji beton ringan mulai terjadi pada saat beban $40 \%$ dari beban maksimumnya. Pola retak yang banyak terjadi pada pengujian ini cukup bervariasi yaitu pola kehancuran geser, kerucut dan geser, serta kerucut dan belah.

\subsection{Pembahasan}

Berdasarkan data pengujian sifat-sifat fisis agregat kasar buatan menunjukkan bahwa nilai bulk density dan specific gravity dalam kondisi OD dan SSD agregat kasar ringan buatan dari tanah diatomae serta agregat kasar ringan buatan dari campuran tanah diatomae dan $5 \%$ serbuk gergaji lebih kecil daripada agregat normal pada umumnya. Jadi agregat kasar yang dibuat ini dapat dijadikan sebagai agregat ringan. Nilai berat volume rata-rata yang diperoleh yaitu $0,724 \mathrm{~kg} / \mathrm{l}$ untuk agregat kasar dari tanah diatomae dan $0,623 \mathrm{~kg} / \mathrm{l}$ untuk agregat kasar dari campuran tanah diatomae dan $5 \%$ serbuk gergaji. Nilai berat volume yang diperoleh untuk agregat halus yaitu $1,684 \mathrm{~kg} / \mathrm{l}$. Nilai berat jenis OD dan SSD rata-rata yang diperoleh yaitu 1,461 dan 1,645 untuk agregat kasar dari tanah diatomae serta 1,360 dan 1,516 untuk agregat kasar dari campuran tanah diatomae dan $5 \%$ serbuk gergaji. Nilai berat jenis dalam kondisi OD dan SSD yang diperoleh untuk agregat halus adalah 2,518 dan 2,575. Nilai absorpsi yang diperoleh yaitu $13,253 \%$ untuk agregat kasar dari tanah diatomae dan 11,499\% untuk agregat kasar dari campuran tanah diatomae dan 5\% serbuk gergaji. Nilai absorpsi yang diperoleh untuk agregat halus yaitu 2,272\%. Hasil Pemeriksaan fineness modulus yang diperoleh yaitu 6,665 untuk agregat kasar dari tanah diatomae dan 6,874 untuk agregat kasar dari campuran tanah diatomae dan
$5 \%$ serbuk gergaji. Nilai fineness modulus yang diperoleh untuk agregat halus yaitu 2,879.

Data pengujian kuat tekan yang diperoleh menunjukkan nilai kuat tekan rata-rata untuk beton ringan dengan variasi agregat kasar ringan buatan dari tanah diatomae yaitu sebesar 17,599 $\mathrm{MPa}$, sedangkan nilai kuat tekan rata-rata untuk beton ringan dengan variasi agregat kasar ringan buatan dari campuran tanah diatomae dan 5\% serbuk gergaji yaitu sebesar 15,368 MPa. Berdasarkan nilai kuat tekan beton ringan yang diperoleh menunjukkan bahwa beton ringan dengan variasi agregat kasar ringan buatan dari tanah diatomae memiliki kekuatan tekan yang lebih tinggi daripada dengan variasi agregat kasar ringan buatan dari campuran tanah diatomae dan 5\% serbuk gergaji. Hal ini disebabkan karena agregat kasar yang berasal dari campuran tanah diatomae dan 5\% serbuk gergaji bersifat lebih lemah sehingga lebih mudah hancur. Berdasarkan nilai kuat tekan beton ringan rata-rata menunjukkan bahwa beton ringan dengan variasi agregat kasar ringan buatan dari tanah diatomae memenuhi persyaratan sesuai dengan SNI 03-3449-2002, yaitu digolongkan ke dalam kelas beton ringan struktural. Sedangkan nilai kuat tekan beton ringan rata-rata dengan variasi agregat kasar ringan buatan dari campuran tanah diatomae dan 5\% serbuk gergaji memenuhi persyaratan sesuai dengan SNI 03-3449-2002, dalam kelas beton ringan struktural ringan.

Dari hasil penelitian, diperoleh nilai modulus elastisitas rata-rata untuk beton ringan dengan variasi agregat kasar ringan buatan dari tanah diatomae yaitu sebesar 12110,11 MPa. Dan modulus elastisitas rata-rata untuk beton ringan dengan variasi agregat kasar ringan buatan dari campuran tanah diatomae dan 5\% serbuk gergaji yaitu sebesar 11844,46 MPa. Dari kedua variasi tersebut nilai modulus elastisitas rata-rata terbesar terdapat pada beton ringan dengan agregat kasar ringan buatan dari tanah diatomae. Hal ini terjadi karena apabila semakin tinggi nilai kekuatan tekan beton, maka nilai modulus elastisitas akan semakin tinggi pula. Berdasarkan hasil kuat tekan beton ringan dan modulus of elasticity yang didapatkan dibuat grafik hubungan modulus elastisitas dan kuat tekan seperti pada Gambar 6. Pada gambar tersebut juga diperlihatkan perbandingan hasil penelitian ini dengan modulus elastisitas menggunakan persamaan menurut SNI 2847:2013, yaitu $E_{c}=W_{c}^{1,5 * 0,043}{ }^{\prime} f_{c}^{\prime}$; persamaan menurut Morales (1982), yaitu $\quad E_{c}=\left(3322 \sqrt{ } f_{c}{ }_{c}+6895\right) \quad\left(W_{c} / 2323\right)^{1,5} ;$ persamaan menurut Tachibana et al. (1994), yaitu $E_{c}=\left(2750 \sqrt{ } f^{\prime}{ }_{c}+1600\right)$; dan persamaan yang diusulkan oleh

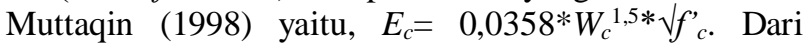
beberapa persamaan tersebut diperoleh hasil yang mendekati dengan hasil penelitian ini adalah persamaan yang diusulkan oleh Tachibana et al. (1994) dan Muttaqin (1998). Sedangkan modulus elastisitas yang dihitung berdasarkan persamaan SNI 2847:2013 dan Morales (1982) mempunyai nilai yang lebih tinggi dibandingkan hasil penelitian ini. 


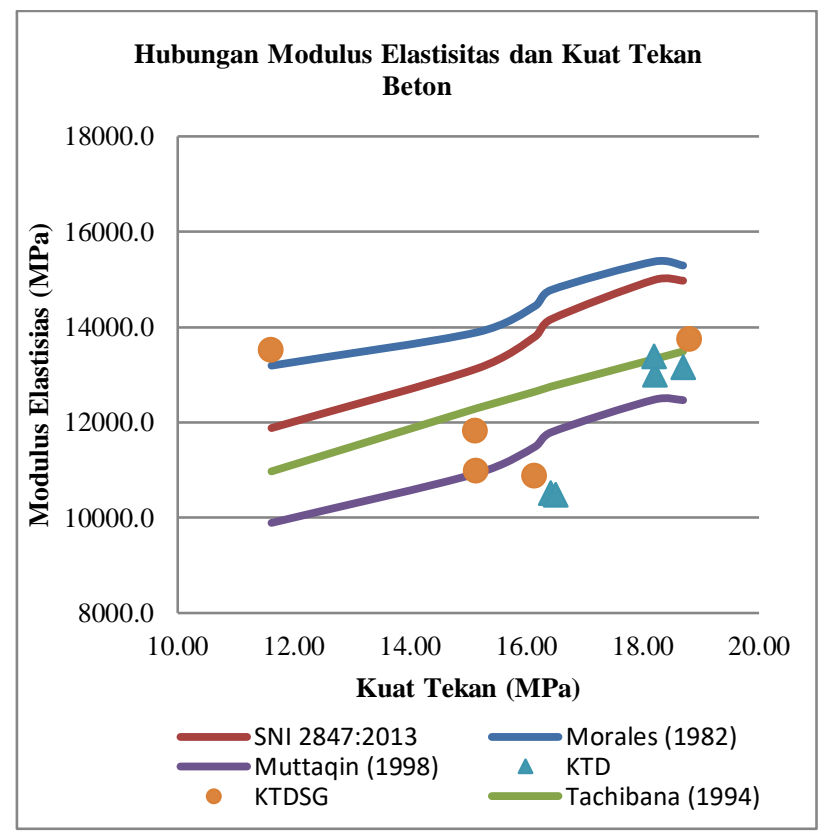

Gambar 6 Grafik Hubungan Modulus Elastisitas dan Kuat Tekan Beton

\section{Kesimpulan dan Saran}

\subsection{Kesimpulan}

1. Dari hasil penelitian menunjukkan bahwa agregat kasar ringan buatan dari tanah diatomae dan dari campuran tanah diatomae dan 5\% serbuk gergaji dapat digunakan sebagai pengganti agregat kasar dalam beton ringan dikarenakan penggunaan agregat kasar ringan buatan ini dapat mengurangi berat volume beton.

2. Nilai kuat tekan beton rata-rata dengan agregat kasar ringan buatan dari tanah diatomae saja yaitu sebesar 17,599 $\mathrm{MPa}$, dan nilai kuat tekan beton rata-rata dengan agregat kasar ringan buatan dari campuran tanah diatomae dan $5 \%$ serbuk gergaji yaitu sebesar 15,368 MPa.

3. Berdasarkan SNI 03-3449-2002 maka beton ringan dengan agregat ringan buatan dari tanah diatomae saja dapat dikelompokkan sebagai beton ringan struktural, sedangkan beton ringan dengan agregat ringan buatan dari campuran tanah diatomae dan 5\% serbuk gergaji dapat dikelompokkan sebagai beton ringan struktural ringan.

4. Nilai modulus elastisitas rata-rata terbesar terdapat pada beton ringan dengan agregat kasar ringan buatan dari tanah diatomae saja yaitu sebesar 12110,11 MPa.

5. Berdasarkan pengamatan penulis, pola kehancuran beton yang terjadi cukup bervariasi yaitu pola kehancuran geser, kerucut dan geser, serta kerucut dan belah.

\subsection{Saran}

1. Diharapkan adanya penelitian lebih lanjut mengenai beton ringan struktural dengan agregat ringan buatan dari tanah diatomae, khususnya dalam pembuatan agregat kasar ringan buatan dimana diharapkan pada penelitian selanjutnya diperoleh agregat kasar ringan buatan yang lebih kuat dan keras dengan cara membakar agregatnya di dalam rotary kiln pada suhu mencapai $1100^{\circ} \mathrm{C}$ sehingga diperoleh kekuatan tekan yang lebih tinggi untuk beton ringan struktural.

2. Untuk penelitian selanjutnya diharapkan agar dapat menambah variasi FAS dan variasi persentase serbuk gergaji dalam agregat yang dibuat. Juga disarankan untuk membuat agregat ringan dari campuran tanah diatomae dan abu terbang.

\section{Daftar Kepustakaan}

[1] Fragoulis, D., Stamatakis M.G., Chaniotakis, E., dan Colombus, G., Characterization of Lightweight Aggregates Produced with Clayey Diatomite Rocks Originating from Greece, Journal of Materials Characterization, 53:307316, 2004.

[2] SNI 2847:2013, Persyaratan Beton Struktural untuk Bangunan Gedung, Badan Standarisasi Nasional, Jakarta, 2013.

[3] Mulyono, T., Teknologi Beton, Penerbit Andi, Yogyakarta, 2004.

[4] ACI Committee 213R-03, Guide for Structural Lightweight-Aggregate, ACI Manual of Concrete Practice, 2003.

[5] SNI 03-3449-2002, Tata Cara Rencana Pembuatan Campuran Beton Ringan dengan Agregat Ringan, Badan Standarisasi Nasional, Bandung, 2002.

[6] Khan, Pesticides in The Soil Environment, Elsevier Scientific Publishing Co, Amsterdam, 1980.

[7] Kristianingrum, S., dan Sulastri, S., Pengaruh Berbagai Asam terhadap Daya Absorpsi Ion Kromium (III) dan Kromium (VI) pada Tanah Diatomae, Jurnal Penelitian Saintek, V(13): No. 1, 77-94, 2008.

[8] Abida, D., Pengaruh Penggunaan Tanah Diatomae Sebagai Substitusi Sebagian Semen terhadap Kuat Tekan Mortar 1:4, Tugas Sarjana, Teknik Sipil, FT Universitas Syiah Kuala, Banda Aceh, 2018.

[9] Kirk and Othmer, Encyclopedia of Chemical Technology, John Wiley and Sons, Fifth Edition, New York, 1979.

[10] SNI 03-1974-1990, Metode Pengujian Kuat Tekan Beton, Badan Standarisasi Nasional, Bandung, 1990.

[11] Gere, J. M., dan Timoshenko, S. P., Mekanika Bahan, terjemahan Hans J. Wospakrik Institut Teknologi Bandung, Edisi Kedua Versi SI., Penerbit Erlangga, Jakarta, 1996.

[12] ASTM C469-02, Standard Test Method for Static Modulus of Elasticity and Poisson's Ratio of Concrete in Compression, International Standards-Worldwide, 2002. 